\title{
HUBUNGAN LAMA MENGIDAP KUSTA DENGAN TINGKAT DEPRESI PADA PASIEN DI RUMAH SAKIT KUSTA SUMBERGLAGAH KABUPATEN MOJOKERTO
}

\section{The Correlation between Duration of Leprosy and Level of Depression in Patient at Sumberglagah Leprosy Hospital Mojokerto District}

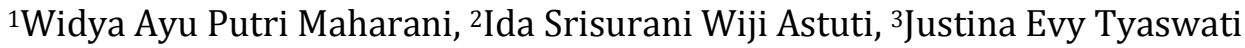 \\ ${ }^{12}$ Fakultas Kedokteran, Universitas Jember \\ ${ }^{3}$ Rumah Sakit Daerah dr. Soebandi Jember \\ Jalan Kalimantan 37, Jember 68121 \\ e-mail: aayuputry@gmail.com
}

\begin{abstract}
Leprosy is a chronic infection disease that caused by Mycobacterium leprae and oftentimes causing negative stigma for people infected by it. The negative stigma and the life quality degradation in people with leprosy lead to the higher risk of depression than people without this disease. Depression is a period of disruption of human function associated with sadness feeling, included changes in sleep pattern and appetite, psychomotor, concentration, anhedonia, fatigue, feeling hopeless, helpless, and having suicidal thoughts. The risk of depression will increase about 2,6 times in people who have chronic illness, one of which is leprosy. This was an analytic observational study with cross sectional approach using 60 respondents chosen by purposive sampling technique. Data were obtained through interview using Hamilton Depression Rating Scale (HDRS) questionnaire and analyzed using Spearman correlation test $(p<0,05)$. The results showed that most respondents $(36,7 \%)$ suffered from leprosy for 0-14 year(s), in which 51,7\% had no depression, 38,3\% had mild depression, $16,7 \%$ had moderate depression, and 3,3\% had severe depression. The analytic results showed the significance value of (p) 0,025 and correlation coefficient of $(r) 0,290$. It could be concluded that there is a correlation between the duration of leprosy and level of depression in patients at Sumberglagah Leprosy Hospital Mojokerto District with weak correlation strength and positive correlation value so it means that the longer the patient suffering from leprosy, the higher the depression level and likewise on the contrary.
\end{abstract}

Keyword: duration of leprosy, level of depression

\begin{abstract}
Abstrak
Kusta merupakan penyakit infeksi kronik yang disebabkan oleh Mycobacterium leprae dan sering menimbulkan stigma negatif bagi pengidapnya. Adanya stigma negatif dan terjadinya penurunan kualitas hidup penderitanya menyebabkan risiko depresi akan lebih tinggi pada penderita kusta daripada masyarakat yang tidak menderita kusta. Depresi merupakan satu masa terganggunya fungsi manusia yang berkaitan dengan alam perasaan yang sedih dan gejala penyertanya, termasuk perubahan pola tidur dan nafsu makan, psikomotor, konsentrasi, anhedonia, kelelahan, rasa putus asa, tidak berdaya, serta rasa ingin bunuh diri. Risiko mengalami depresi akan meningkat sebesar 2,6 kali lipat pada orang yang memiliki suatu penyakit kronis, salah satunya kusta. Jenis penelitian ini adalah analitik observasional dengan dengan pendekatan cross sectional. Sampel sebesar 60 responden diambil dengan teknik purposive sampling. Data didapatkan melalui wawancara dengan kuesioner Hamilton Depression Rating Scale (HDRS) dan dianalisis menggunakan uji korelasi Spearman $(\mathrm{p}<0,05)$. Hasil penelitian menunjukkan lama pasien

12 Widya Ayu Putri Maharani dan Ida Srisurani Wiji Astuti adalah Fakultas Kedokteran Universitas Jember

3 Justina Evy Tyaswati adalah Rumah Sakit Daerah dr. Soebandi Jember
\end{abstract}


$51,7 \%$ pasien tidak mengalami depresi, 38,3\% pasien mengalami depresi ringan, $16,7 \%$ pasien mengalami depresi sedang, dan 3,3\% pasien mengalami depresi berat. Hasil analisis menunjukkan nilai signifikansi (p) 0,025 dan nilai koefisien korelasi (r) 0,290. Dapat disimpulkan bahwa terdapat hubungan antara lama mengidap kusta dan tingkat depresi pada pasien di Rumah Sakit Kusta Sumberglagah Kabupaten Mojokerto dengan kekuatan korelasi lemah dan nilai korelasi positif sehingga dapat diartikan bahwa semakin lama pasien mengidap kusta maka semakin tinggi tingkat depresinya. Begitupun sebaliknya, semakin singkat pasien menderita kusta, maka semakin rendah.

Kata kunci: lama menderita kusta, tingkat depresi

\section{PENDAHULUAN}

Kusta merupakan penyakit infeksi yang kronik dan disebabkan oleh Mycobacterium leprae yang bersifat intraselular obligat. Saraf perifer sebagai afinitas pertama, kemudian menyerang kulit, mukosa (mulut), saluran pernafasan bagian atas, sistem retikulo endotelial, mata, otot, tulang dan testis [1], kemudian dapat ke organ lain kecuali susunan saraf pusat [2].

Pada pasien yang telah muncul gejala-gejala dan didiagnosis mengidap kusta, tentu akan mengalami halangan dalam menjalani kehidupan bermasyarakat untuk memenuhi kebutuhan hidup alamiahnya. Hal ini disebabkan karena stigma negatif mengenai penyakit kusta masih melekat erat di benak masyarakat. Adanya stigma negatif dan terjadinya penurunan kualitas hidup penderita kusta akan berkesinambungan dengan munculnya masalah psikis yang lebih parah, salah satunya depresi.

Depresi merupakan satu masa terganggunya fungsi manusia yang berkaitan dengan alam perasaan yang sedih dan gejala penyertanya, termasuk perubahan pola tidur dan nafsu makan, psikomotor, konsentrasi, anhedonia, kelelahan, rasa putus asa dan tidak berdaya, serta rasa ingin bunuh diri. Risiko mengalami depresi akan meningkat sebesar 2,6 kali lipat pada orang yang memiliki suatu penyakit kronis [3] dan tingkat depresi akan lebih tinggi pada penderita kusta daripada masyarakat umum akibat dari stigma negatif yang disebabkan oleh kusta [4]. Hal ini mendasari penulis untuk melakukan penelitian dengan tujuan untuk mengetahui hubungan lama mengidap kusta dengan tingkat depresi pada pasien di Rumah Sakit Kusta Sumberglagah Kabupaten Mojokerto.

Manfaat dari penelitian ini adalah dapat memberikan informasi pada pasien kusta agar lebih memperhatikan kondisi psikologisnya yang muncul akibat stigma negatif dari masyarakat dan keterbatasan yang muncul karena penyakit kusta serta sebagai bahan pertimbangan perlunya perawatan intensif antara bidang penyakit kulit dan psikiatri.

\section{METODE}

Jenis penelitian ini adalah analitik observasional dengan desain penelitian cross sectional. Penelitian ini dilakukan di Poli Rawat Jalan Ruang Melati Rumah Sakit Kusta Sumberglagah Kabupaten Mojokerto pada bulan Juli 2017 dalam kurun waktu 1 (satu) minggu dan telah mendapatkan persetujuan etik (ethical approval) dari Komisi Etik Fakultas Kedokteran Jember dan Komisi Etik Rumah Sakit Kusta Sumberglagah Kabupaten Mojokerto.

Besar sampel pada penelitian ini adalah 60 orang pasien yang diambil menggunakan teknik purposive sampling 
dengan kriteria inklusi sampel adalah berusia 18-80 tahun dan terdaftar sebagai pasien kusta di Rumah Sakit Kusta Sumberglagah Kabupaten Mojokerto. Sedangkan kriteria ekslusi sampel adalah tidak menyelesaikan proses interview atau pengisian kuesioner, dan menderita depresi sangat berat dan/atau gangguan jiwa berat.

Alat yang digunakan dalam penelitian ini terdiri dari formulir informed consent, lembar wawancara dan kuesioner Hamilton Depression Rating Scale (HDRS) yang digunakan untuk mengukur tingkat depresi pada pasien. Interpretasi kuesioner ini adalah $<17$ tidak mengalaami depresi, 18-24 mengalami depresi ringan, 25-34 mengalami depresi sedang, 35-51 mengalami depresi berat, dan 52-68 mengalami depresi berat.

Data yang terkumpul dianalisis menggunakan uji korelasi Spearman karena jenis data kedua variabel yang diuji dalam penelitian ini adalah ordinal.

\section{HASIL PENELITIAN}

Reponden dalam penelitian ini adalah 60 responden dan data yang terkumpul dapat dilihat pada Tabel 1.

Tabel 1. Distribusi Responden (pasien)

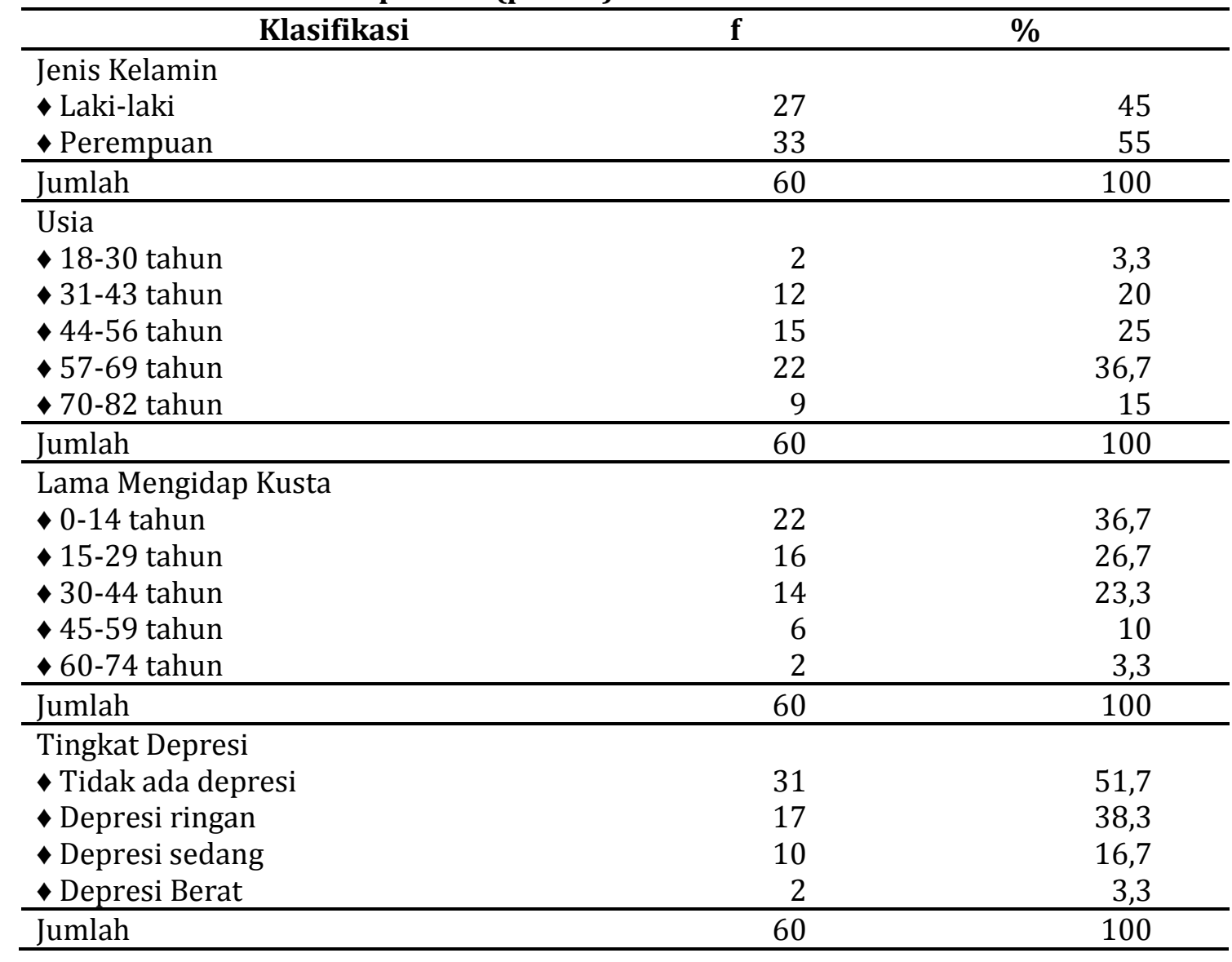

Berdasarkan Tabel 1 dapat diketahui bahwa responden terbanyak adalah pasien perempuan sebesar 55\%. Kelompok umur terbanyak adalah umur
57-69 tahun sebesar 36,7\%. Lama pasien mengidap kusta terbanyak adalah selama 0-14 tahun sebesar 36,7\%. Ditemukan sebanyak $51,7 \%$ pasien tidak mengalami 
depresi, $38,3 \%$ pasien mengalami depresi ringan, $16,7 \%$ pasien mengalami depresi sedang, dan $3,3 \%$ pasien mengalami depresi berat.

Setelah diketahu distribusi responden, maka dilakukan distribusi silang lama mengidap kusta dengan jenis kelamin dan umur (Tabel 2), distribusi silang tingkat depresi dengan jenis kelamin dan umur (Tabel 3), serta distribusi silang lama mengidap kusta dengan tingkat derpesi (Tabel 4).

\section{Uji Spearman}

Hasil uji korelasi spearman dapat dilihat pada Tabel 5. Berdasarkan tabel tersebut, didapatkan nilai signifikansi (p) 0,025. Dapat disimpulkan bahwa terdapat hubungan antara lama mengidap kusta dengan tingkat depresi pada pasien di Rumah Sakit Kusta Sumberglagah Kabupaten Mojokerto. Nilai koefisien korelasi (r) 0,290 menunjukkan kekuatan korelasi yang lemah dengan arah positif.. Dapat disimpulkan bahwa semakin lama pasien mengidap kusta maka semakin tinggi tingkat depresinya. Begitupun sebaliknya, semakin singkat pasien menderita kusta, maka semakin rendah tingkat depresinya.

Tabel 5. Hasil uji korelasi Spearman

\begin{tabular}{lc}
\hline \multicolumn{2}{c}{ Hasil Korelasi antara Lama Mengidap Kusta dengan Tingkat Depresi } \\
\hline Koefisien Korelasi & r 0,290 \\
Signifikansi & P 0,025 \\
\hline Jumlah Data & $\mathrm{n} 60$ \\
\hline
\end{tabular}

\section{PEMBAHASAN}

Berdasarkan hasil penelitian, ditemukan pasien dengan lama mengidap kusta selama 0-14 tahun paling banyak mengalami depresi ringan sebesar 7 responden $(11,7 \%)$, sedangkan responden yang tidak mengalami depresi yaitu sebesar 13 responden $(21,7 \%)$. Hal ini menunjukkan bahwa pasien kusta di Rumah-

Tabel 2. Distribusi silang lama mengidap kusta dengan jenis kelamin dan umur

\begin{tabular}{|c|c|c|c|c|c|c|c|c|c|c|c|c|}
\hline \multirow{3}{*}{ Klasifikasi } & \multicolumn{10}{|c|}{ Lama Mengidap Kusta (Tahun) } & \multirow{2}{*}{\multicolumn{2}{|c|}{ Total }} \\
\hline & \multicolumn{2}{|c|}{$0-14$} & \multicolumn{2}{|c|}{$15-29$} & \multicolumn{2}{|c|}{$30-44$} & \multicolumn{2}{|c|}{$45-59$} & \multicolumn{2}{|c|}{$60-74$} & & \\
\hline & $\mathrm{f}$ & $\%$ & $\mathrm{f}$ & $\%$ & $\mathrm{f}$ & $\%$ & $f$ & $\%$ & $\mathrm{f}$ & $\%$ & $\mathrm{f}$ & $\%$ \\
\hline \multicolumn{13}{|l|}{ Jenis Kelamin } \\
\hline Laki-laki & 8 & 13,3 & 10 & 16,7 & 5 & 8,3 & 3 & 5 & 1 & 1,7 & 27 & 45 \\
\hline Perempuan & 14 & 23,3 & 6 & 10 & 9 & 15 & 3 & 5 & 1 & 1,7 & 33 & 55 \\
\hline Jumlah & 22 & 36,7 & 16 & 26,7 & 14 & 23,3 & 6 & 10 & 2 & 3,3 & 60 & 100 \\
\hline \multicolumn{13}{|l|}{ Usia } \\
\hline 18-30 tahun & 2 & 3,3 & 0 & 0 & 0 & 0 & 0 & 0 & 0 & 0 & 2 & 3,3 \\
\hline -31-43 tahun & 10 & 16,7 & 2 & 3,3 & 0 & 0 & 0 & 0 & 0 & 0 & 12 & 20 \\
\hline 44-56 tahun & 7 & 11,7 & 7 & 11,7 & 5 & 8,3 & 0 & 0 & 0 & 0 & 19 & 31,7 \\
\hline 57-69 tahun & 2 & 3,3 & 5 & 8,3 & 9 & 15 & 2 & 3,3 & 0 & 0 & 18 & 30 \\
\hline - 70-82 tahun & 1 & 1,7 & 2 & 3,3 & 0 & 0 & 4 & 6,7 & 2 & 3,3 & 9 & 15 \\
\hline Jumlah & 22 & 36,7 & 16 & 26,6 & 14 & 23,3 & 6 & 10 & 2 & 3,3 & 60 & 100 \\
\hline
\end{tabular}


Tabel 3. Distribusi silang tingkat depresi dengan jenis kelamin dan umur

\begin{tabular}{|c|c|c|c|c|c|c|c|c|c|c|}
\hline \multirow{3}{*}{ Klasifikasi } & \multicolumn{8}{|c|}{ Tingkat Depresi } & \multirow{2}{*}{\multicolumn{2}{|c|}{ Total }} \\
\hline & \multicolumn{2}{|c|}{$\begin{array}{c}\text { Tidak ada } \\
\text { Depresi }\end{array}$} & \multicolumn{2}{|c|}{$\begin{array}{l}\text { Depresi } \\
\text { Ringan }\end{array}$} & \multicolumn{2}{|c|}{$\begin{array}{l}\text { Depresi } \\
\text { Sedang }\end{array}$} & \multicolumn{2}{|c|}{$\begin{array}{c}\text { Depresi } \\
\text { Berat }\end{array}$} & & \\
\hline & $\mathrm{f}$ & $\%$ & $f$ & $\%$ & $f$ & $\%$ & $\mathrm{f}$ & $\%$ & $\mathrm{f}$ & $\%$ \\
\hline \multicolumn{11}{|l|}{ Jenis Kelamin } \\
\hline • Laki-laki & 16 & 26,7 & 5 & 8,3 & 5 & 8,3 & 1 & 1,7 & 27 & 45 \\
\hline Perempuan & 15 & 25 & 12 & 20 & 5 & 8,3 & 1 & 1,7 & 33 & 55 \\
\hline Jumlah & 31 & 51,7 & 17 & 28,3 & 10 & 16,6 & 2 & 3,4 & 60 & 100 \\
\hline \multicolumn{11}{|l|}{ Usia } \\
\hline 18-30 tahun & 0 & 0 & 0 & 0 & 2 & 3,3 & 0 & 0 & 2 & 3,3 \\
\hline • 31-43 tahun & 7 & 11,7 & 5 & 8,3 & 0 & 0 & 0 & 0 & 12 & 20 \\
\hline 44-56 tahun & 11 & 18,3 & 6 & 10 & 2 & 3,3 & 0 & 0 & 19 & 31,7 \\
\hline 57-69 tahun & 12 & 20 & 5 & 8,3 & 1 & 1.7 & 0 & 0 & 18 & 30 \\
\hline - 70-82 tahun & 1 & 1,7 & 1 & 1,7 & 5 & 8,3 & 2 & 3,3 & 9 & 15 \\
\hline Jumlah & 31 & 51,7 & 17 & 28,3 & 10 & 16,6 & 2 & 3,3 & 60 & 100 \\
\hline
\end{tabular}

Tabel 4. Distribusi silang lama mengidap kusta dengan tingkat depresi

\begin{tabular}{|c|c|c|c|c|c|c|c|c|c|c|}
\hline \multirow{3}{*}{$\begin{array}{c}\text { Lama } \\
\text { Mengidap } \\
\text { Kusta } \\
\end{array}$} & \multicolumn{5}{|c|}{ Tingkat Depresi } & \multicolumn{5}{|c|}{ Total } \\
\hline & \multicolumn{2}{|c|}{ Tidak ada } & \multicolumn{2}{|c|}{ Ringan } & \multicolumn{2}{|c|}{ Sedang } & \multicolumn{2}{|c|}{ Berat } & \multirow[b]{2}{*}{$\mathrm{F}$} & \multirow[b]{2}{*}{$\%$} \\
\hline & $\mathrm{f}$ & $\%$ & $\mathrm{f}$ & $\%$ & $\mathrm{f}$ & $\%$ & $\mathrm{f}$ & $\%$ & & \\
\hline 0-14 tahun & 13 & 21,7 & 7 & 11,7 & 2 & 3,3 & 0 & .0 & 22 & 36,7 \\
\hline -15-29 tahun & 8 & 13,3 & 6 & 10 & 2 & 3,3 & 0 & .0 & 16 & 26,7 \\
\hline - 30-44 tahun & 9 & 15 & 4 & 6,7 & 1 & 1,7 & 0 & .0 & 14 & 23,3 \\
\hline 45-59 tahun & 1 & 1,7 & 0 & .0 & 4 & 6,7 & 1 & 1,7 & 6 & 10 \\
\hline 60-74 tahun & 0 & .0 & 0 & .0 & 1 & 1,7 & 1 & 1,7 & 2 & 3,3 \\
\hline
\end{tabular}

Sakit Kusta Sumberglagah Kabupaten Mojokerto lebih banyak yang tidak mengalami depresi. Pasien kusta di Rumah Sakit Kusta Sumberglagah Kabupaten Mojokerto rutin mendapatkan pendidikan kesehatan dari pihak rumah sakit melalui penyuluhan rutin satu kali dalam sebulan. Penyuluhan ini dapat digunakan pihak rumah sakit untuk meningkatkan ketahanan pasien pada depresi melalui self-efficacy sehingga mekanisme koping individu makin baik. [5] menyebutkan bahwa semakin tinggi tingkat selfefficacy maka semakian tinggi pula tingkat optimisme dan kepercayaan diri pasien terhadap kemampuannya dalam memecahkan masalahnya sendiri.
Respon koping yang dapat diterapkan pada individu adalah mekanisme adaptif dan maladaptive [6]. Salah satu cara dari respon koping adalah mekanisme koping. Mekanisme koping merupakan mekanisme yang digunakan oleh individu umtuk menghadapi perubahan yang diterima. Apabila mekanisme koping koping berhasil, maka individu tersebut akan dapat beradaptasi pada perubahan yang terjadi. Namun apabila respon koping tersebut tidak berhasil, maka akan menimbulkan Namun apabila respon koping tersebut tidak berhasil, maka akan menimbulkan gangguan kesehatan baik fisik maupun psikologis [7] yang dapat mempengaruhi proses penyembuhan penyakit kusta. 
Selain itu, dukungan sosial baik dari keluarga maupun lingkungan juga mempengaruhi kondisi psikologis penderita. Semakin baik dukungan sosial dari keluarga dan lingkungan, maka semakin baik pula kondisi psikologis penderita kusta. Secara fisik dukungan sosial dari keluarga berupa bantuan tenaga untuk memenuhi kebutuhan aktivitas sehari-hari. Sedangkan secara psikologis dukungan sosial dapat berbentuk kasih sayang, membantu mengambangkan konsep diri pasien kearah yang positif dan menerima pasien sesuai dengan perubahan-perubahan yang dialami saat sakit. Dimungkinkan kondisi psikologisnya akan lebih tahan terhadap depresi dikarenakan pasien sudah lebih siap daripada sebelumnya dalam menghadapi penyakit ini. Pasien sudah terbiasa dengan segala pengobatan dan pola kehidupan. Tentunya pengetahuan pasien terhadap penyakit kusta yang dideritanya semakin lama akan semakin banyak, dan pada tahap ini pasien tidak lagi dibingungkan oleh informasi yang simpang siur tentang penyakitnya.

Distribusi tingkat depresi menurut jenis kelamin menunjukkan dari 60 responden yang diteliti yaitu sebesar 20\% menyatakan bahwa perempuan lebih banyak mengalami depresi ringan daripada laki-laki. Hal ini menunjukkan jika laki-laki memiliki coping mechanism yang lebih baik untuk menghadapi masalah-masalah dalam sehari-hari yang dapat menyebabkan kecenderungan akan depresinya. Perempuan cenderung lebih mudah terkena stress karena fluktuasi hormon saat menstruasi, saat post-partum, dan saat menoupose yang bepengaruh terhadap keseimbangan kimiawi otak sehingga menimbulkan kecemasan [8]. Salah satu faktor yang menyebabkan wanita lebih rentan mengalami depresi dipengaruhi estrogen dan progesteron [9].

Berdasarkan hasil penelitian yang dilakukan, telah diperoleh data distribusi tingkat depresi berdasarkan umur menunjukkan bahwa 6 responden mengalami depresi ringan pada kelompok umur 44-56 tahun yang merupakan kelompok golongan dewasa akhir menuju lansia awal [10] dan sebanyak 12 responden tidak mengalami depresi pada kelompok umur 57-69 tahun yang merupakan kelompok golongan lansia akhir [10]. Terdapat perbedaan antara hasil penelitian ini yang menunjukkan bahwa responden yang tidak mengalami depresi lebih banyak dibanding yang mengalami depresi, dengan teori yang dikemukakan oleh [11] yaitu lansia merupakan tahap lanjut dari suatu proses kehidupan yang ditandai dengan penurunan kemampuan tubuh untuk beradaptasi dengan stress lingkungan. Hal ini karena pada proses penuaan akan terjadi berbagai perubahan dimulai dari perubahan fungsi fisik, kognitif sampai perubahan psikososial yang akan mempermudah terjadinya depresi pada lansia. Bertambahnya usia maka secara alamiah juga akan mempengaruhi terjadi penurunan kemampuan seperti fungsi perawatan diri sendiri, berinteraksi dengan orang lain disekitar dan semakin bergantung dengan yang lain [12]. Hal ini dapat disebabkan karena adanya dukungan keluarga yang baik bagi para lansia, dimana dukungan keluarga sangat penting bagi lansia seperti dukungan emosional, dukungan psikologis, dukungan sosial sehinggan penekaan terhadap stress yang akan berkembang menjadi depresi akan berkurang [13].

Penelitian ini sendiri menghadapi keterbatasan diantaranya adalah penggunaan metode kuesioner dengan 
teknik wawancara yang masih bersifat subjektif dikarenakan hanya berdasarkan apa yang dirasakan responden penelitian, maka dari itu diperlukan penelitian lebih lanjut secara objektif dengan menggunakan peralatan yang lebih canggih.

\section{SIMPULAN DAN SARAN}

Berdasarkan pembahasan diatas, didapatkan mayoritas $\quad(21,7 \%)$ responden dari 60 sampel dengan lama mengidap kusta selama 0-14 tahun tidak mengalami depresi, serta pada hasil analisis data dan pembahasan dapat disimpulkan bahwa terdapat hubungan antara mengidap kusta dengan tingkat depresi pada pasien kusta di Rumah Sakit Sumberglagah Kabupaten Mojokerto. Analisis hubungan antara kedua variabel tersebut menunjukkan kekuatan korelasi lemah dengan nilai korelasi positif sehingga dapat diartikan bahwa semakin lama pasien mengidap kusta maka semakin tinggi tingkat depresinya. Begitupun sebaliknya, semakin singkat pasien menderita kusta, maka semakin rendah.

\section{DAFTAR PUSTAKA}

[1] Harahap, M. 2000. Ilmu Penyakit Kulit. Jakarta: Hipokrates.

[2] Djuanda, A. 2007. Ilmu Penyakit Kulit dan Kelamin. Jakarta: FKUI.

[3] Widakdo, G., dan Besral. 2013. Efek penyakit kronis terhaap gangguan mental emosional. Jurnal Kesehatan Masyarakat Nasional. 7(7):309-316.

[4] Tsutsumi, A., T. Izutzu, M. D. A. Islam, J. U. Amed, S. Nakahara, F. Takagi, dan S. Wakai. 2004. Depressive status of leprosy patients in Bangladesh: association with self-perception of stigma. Lepr Rev. 75: 57-66.

[5] Septiani, T., dan N. Fitria. 2016. Hubungan antara resiliensi dengan stres pada mahasiswa Sekolah Tinggi Kedinasan. Jurnal Peneitian Psikologi. 7(2):59-76.

[6] Ihdaniyati, A.I., dan S. Arifah. 2009. Hubungan tingkat kecemasan dengan mekanisme koping pada pasien gagal jantung kongestif di RSU Pandan Arang Boyolali. Berita Ilmu Keperawatan ISSN 19792697. 2(1):19-24.

[7] Rasmun. 2004. Stres, Koping dan Adaptasi: Teori dan Pohon Keperawatan. Jakarta: Sagung Seto.

[8] McLean, C.P., A. Asnaani, B. T. Litz, dan S. G. Hofmann. 2011. Gender differences in anxiety disorders: prevalence, course of illness, comorbidity and burden of illness. Psychiatr Res. 45(8): 1027-1035.

[9] Christensen, J., M.J. Kjeldsen., H. Andersen., M.L Friis, dan P. Sidenius. 2005. Gender Differences in Epilepsy. Epilepsia, 46 (6): 956960.

[10] Departemen Kesehatan Republik Indonesia. 2009. Profil Kesehatan Indonesia. Jakarta: Depkes RI.

[11] Kaplan, H. \& Sadock, B. 2010. Sinopsis Psikiatri Ilmu Pengetahuan Psikiatri Klinis. Jakarta: Binarupa Aksara.

[12] Rinajumita. (2011). Faktor-faktor yang berhubungan dengan kemandirian lansia wilayah kerja puskesmas Lampasi Kecamatan Payakumbuh Utara. http://repository.unand.ac.id/168 84/1/FAKTORFAKTOR_YANG_BER HUBUNGAN_DENGAN_KEMANDIRI AN_LANSIA.Pdf. [Diakses pada 14 Desember 2017] 
64 Jurnal IKESMA Volume 14 Nomor 1 Maret 2018

[13] Santoso, H., dan A. Ismail. 2009.

Memahami Krisis Lanjut Usia:

Uraian Medisdan Pedagogis-

Pastoral. Jakarta: BPK Gunung

Mulia. 